\title{
Youth Education in Self-Preparing as Marine Ecotourism Guide in Kepulauan Seribu
}

\author{
Tuty Handayani \\ Department of Geography, University of Indonesia \\ Depok, Jawa Barat, Indonesia \\ Corresponding email: tuty.handayani@ui.ac.id \\ tutyhand@gmail.com \\ Elgodwistra Kartikoputro \\ Department of Geography, University of Indonesia \\ Depok, Jawa Barat, Indonesia \\ A Harsono Soepardjo \\ Department of Geography, University of Indonesia \\ Depok, Jawa Barat, Indonesia
}

\begin{abstract}
Marine Ecotourism is a form of tourism that stil ensures the sustainability of the sea ecosystem. Tidung Island in the district of Kepulauan Seribu Selatan and Harapan Island in the District of Kepulauan Seribu Utara, has a different characteristics. However, both the islands intended as a tourist destination, as well as a conservation area. To ensure the sustainability of marine ecotourism, that the coastal ecosystems must be preserved. To understand the readiness of the school-age youth in marine ecotourism activities, interviews were conducted with some junior high school students in the two islands, along with training for monitoring the conservation of coastal ecosystems. Training activities include monitoring coral reef by using the Coral Health Chart, observing the condition of seagrass through Seagrass Watch method, and the introduction of mangrove ecosystems. The results show, Harapan Island that located farther from Jakarta mainland has a sea ecosystem that good quality. Most of the youth here is fisherman's children and ready to be prepared and involved in the marine ecotourism development. About $80 \%$ of them have a good ability in monitoring the coastal ecosystems. While the youth in Tidung Island, which is closer to Jakarta and has been developed as a tourist area for a while, are more expert in coastal tourism that tend to be recreational. Only $30 \%$ of them were prepared to do the monitoring of coastal ecosystems. It can be concluded that the younger generation on the islands farther from the city tend to be better prepared to involved in marine ecotourism development.
\end{abstract}

Keywords-Kepulauan Seribu, tourism areas, monitoring coastal ecosystems, youth education, marine conservation area

\section{INTRODUCTION}

Kepulauan Seribu Regency consist of Kepulauan Seribu Selatan District and Kepulauan Seribu Utara District. Kepulauan Seribu Selatan District consist of Pulau Tidung subdistrict (which is located in Tidung Island), Pulau Pari subdistrict, and Pulau Untung Jawa sub-district. Kepulauan Seribu Utara District consist of Pulau Panggan sub-district, Pulau
Kelapa sub-district, and Pulau Harapan sub-district (which is located in Kelapa Island)

Marine tourism in the Kepulauan Seribu is inseparable from the existence of Taman Nasional Kepulauan Seribu (TNKS / Kepulauan Seribu National Park) that mostly located in the District of Kepulauan Seribu Utara. The area in TNKS divided into few zones, there are the Core Zone, the Protection Zone, the Tourism Utilization Zone, and the Residential Zone.

Pulau Tidung, located in Kepulauan Seribu Selatan, is a very busy tourist destination. In 2014, the number of tourist visits as many as 113,211 persons (Pulau Tidung Village Office, 2015). However, due to the many tourists who come, that it has caused the destruction of ecosystems, especially coral reefs (Ruswadi, 2012)

Harapan Island, located in Kepulauan Seribu Utara, is part of residential zone the TNKS region. It were areas a fishing village, and until now there are many people who work as fisherman. But the recently, Harapan Island also started to be crowded by tourists.

On the Harapan Island and Tidung Island, there are ecosystem conservation area called Daerah Perlindungan Laut (DPL) / Marine Protected Areas (MPAs), an area which is now filled with coral reefs and transplanted corals. The MPAs existence must be kept out of tourists, as a continuous effort needed to maintain it.

Then to preserve the marine environment in the future, the local society as tour guides should be able to apply the concept of marine ecotourism, so they also have to understand the monitoring and conservation of coastal ecosystems. Education about understanding the ecosystem is very well done during teen age.

This is done so that the principles of conservation can be embedded properly (interlized) 

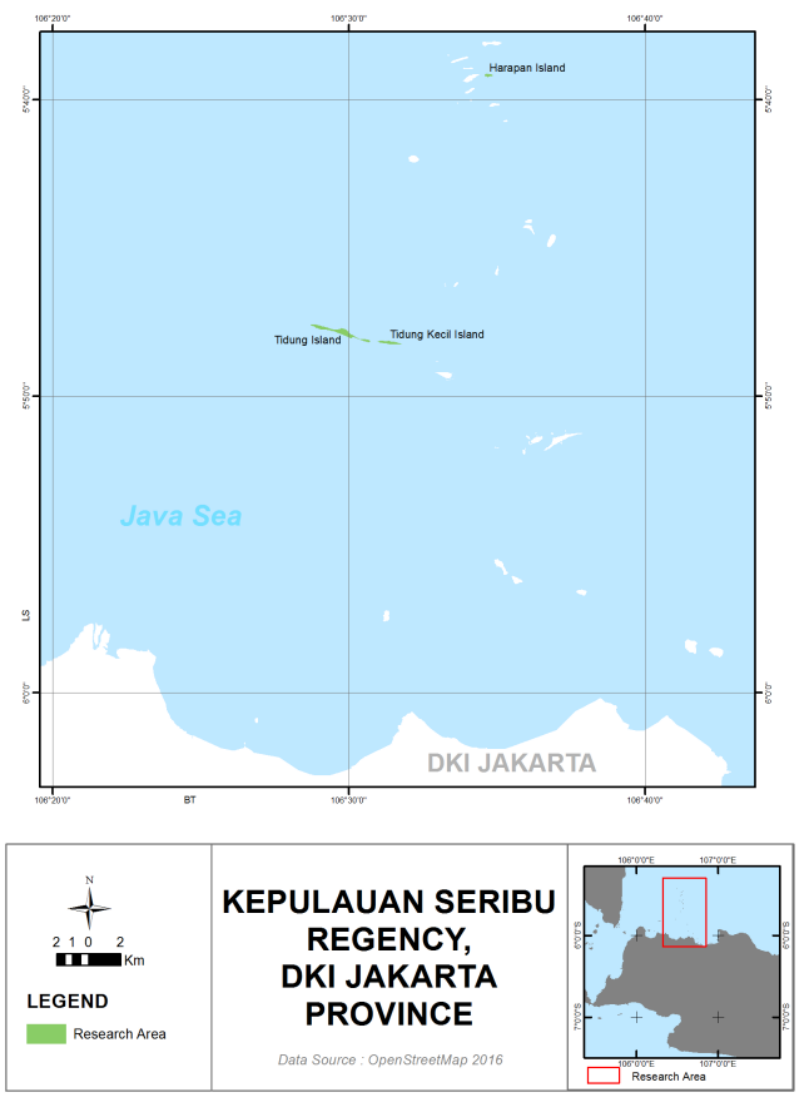

Fig.1. Tidung Island and Harapan Island

The purpose of this study was to determine whether the differences in location affects teen's attitude and their readiness as a candidate for a tour guide in marine Ecotourism. Readiness is not only from the desire and attitude, but also the ability inside doing conservation and monitoring of the marine environment.

\section{METHOD}

The research areas are located in two locations, Tidung Island which represents the District of Kepulauan Seribu Selatan has a distance approximately $45 \mathrm{~km}$ from Muara Angke, Jakarta. While Harapan Island which representing District of Kepulauan Seribu Utara is no more than $54 \mathrm{~km}$. Both were developed as tourist areas and also had the MPAs.

This study was conducted on 40 teens of junior high school in grades seventh until ninth (aged 12 to 16 years). Each of island represented by 20 teenagers, and the sample consisted of students come from the faith-based schools and public schools.

The first stage is the introduction of Coastal Ecosystem. This is conducted to practice the monitoring activities and environmental conservation. The method was to invite the learners practice to mangrove observation in the beach, started from the mangrove observation that related to its type and density. Then the next activity is observe the density and growth of the seagrass with the Seagrass Watch method and monitoring the coral reef by using the Coral Health Chart.

The second stage is conducting interviews. Interviews addressed to students using a questionnaire method. In the questionnaire, the question that raised is about their views on the condition of marine tourism at this time, their desire to formed of tourism which is considered ideal for the preservation of the environment, and understanding of the need to conserve the coastal ecosystem, and their expectations for the condition of their island that now it's been crowded by tourists.

The third stage is to combine the obtained answers during the interview with the ability while following the practice in the sea. The activities carried out by a group discussion. The group consists of five people. Each group discussions guided by a facilitator who is also a mentor when practice at sea. From the discussion can be structured the matrix and drawn conclusions.

\section{FINDING AND DISCUSSION}

\section{A. Harapan Island and Tidung Island.}

Harapan Island is located in the Kepulauan Seribu Utara, at coordinates $05^{\circ} 39^{\prime} 10$ " $\mathrm{S}$ and $106^{\circ} 34^{\prime} 41^{\prime \prime} \mathrm{E}$ with the size is 6.7 ha. Most of the residents are migrants, coming from Mandar, Bugis, and Javanese tribes. The main livelihood of the population as a fisherman. Harapan Island is an island where tourists stay during marine tourism. Marine tourism spots like snorkeling and diving spots are located in small islands around the Harapan island, while there's some small island too that very close with the core area of TNKS. In the past, Harapan Island was a fishing settlement village that is now developed into a tourism village. Based on the data that in 2011 there were only 16 specialty lodging, and increased to 86 in 2013 and to 119 at January 2015. Most of the students that involved in this study are children of fishermen.

Tidung island is located in the Kepulauan Seribu Selatan with Coordinates: $5^{\circ} 48^{\prime} 12^{\prime \prime} \mathrm{S}$ and $106^{\circ} 31^{\prime} 24^{\prime \prime} \mathrm{E}$. Tidung island consists of two islands, named Pulau Tidung Besar and Pulau Tidung Kecil. The uninhibited Tidung Kecil is a special area for mangrove conservation as well as several other plant species. Both islands are connected with a bridge that called Jembatan Cinta, which now become the attraction icon of Tidung island.

The inhabited island as to serves the tourists destination is the Tidung Besar. Almost all the houses on the waterfront has become Homestays. Although most residents are fisherman, but there are 24 percents of the residents that work in other fields. (Suryati, 2008). In Tidung island, there are many women that help earn a living, to serve the needs of travelers and also do trading. The other people beside the pure fisherman's children, the students that involved in this study also are fisherman's children who has moved into a tourism business operators and traders. Not only snorkeling and diving activities, in Pulau Tidung Besar there are also various beach 
sports activities. Among others are Banana Boat, Sofa Boat, and Canoe.

\section{B. The Introduction Coastal Ecosystems Practice Results The introduction of Mangrove.}

Students were invited to the mangrove location, identify the types of mangrove, mangrove properties, and the functions of mangrove. Each group compares mangrove species in the field with the examples provided in the worksheet. Students use a rope and made a transect for calculate mangroves density.

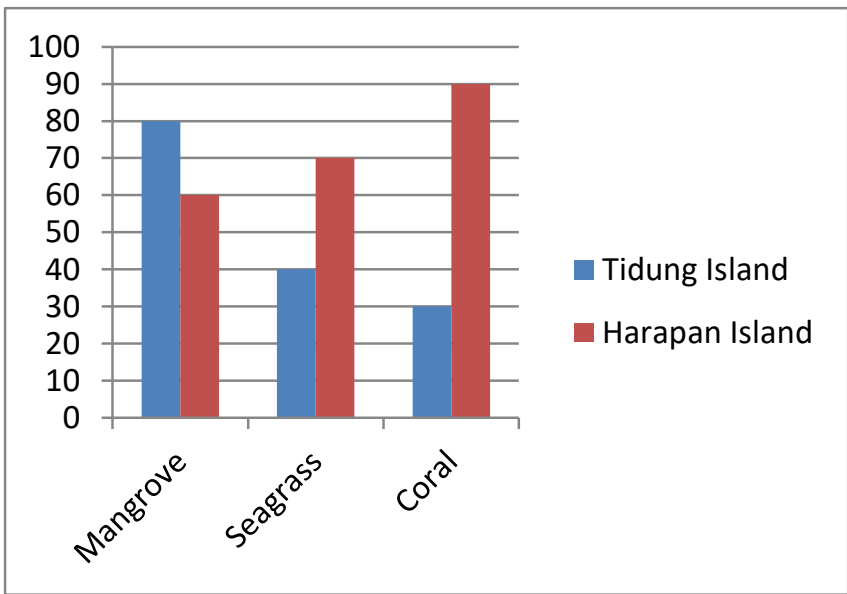

Fig.2. Percentage of students' competence in the field practice

Skills in measuring the density of mangrove, is almost the same among students in Tidung and students in Harapan Island. At Tidung many mangroves were lost and now still not recovered yet, but the knowledge about the types of mangrove, mangrove functions, and the properties mangrove of roots more better than students from Harapan Island. Students at Harapan Island just know about the mangroves that were planted in Harapan Island at that time as a government program.

\section{- The introduction of Seagrass}

The study of density and species of seagrasses, and their own practice within the measurement by using the Seagrass Watch methods, all of groups students can perform properly in a short time. The ability to analyze and assess the types of seagrass densities are also similar between students of Tidung Island and Harapan Island. The differences lies on their desirel when were observing. The students from Harapan Island appears to be have more desire to be able to monitor seagrass. While the student groups in Tidung were doing it right, but their appear to be less unified, because there were some member of the group that was less serious.

- The introduction of Coral Reefs

Field practice for studying and monitoring coral reef is the most interesting activities. All participants must learn how to use the snorkel mask to be able to observe coral reefs with transect techniques and Coral Health Chart methods. Students take measurements in healthy corals and dead or bleaching corals. All students are also taught how to contribute data that can be accessed to anyone that requires the data over the internet.

In this field practice, it turns out there is a difference in skill of coral reef measuring. The groups of students from the Harapan Islands more quick mastering the techniques, more excited because they can be stay quite long in the water. The ability of characteristics children who live around the water is obviously required. As for the groups that come from the Tidung island are less resistant to stay on the water, so they need more time to absorb the techniques and ways of monitoring coral reefs. It was seen that the increase in psychomotor abilities more noticeable in the student groups from Harapan Island.

\section{Interview Results The Readiness as a Tour Guide.}

As a junior high school student, the students has the various aspiration. All of them are willing to be a marine tour guide, but the reason of their willingness can be divided into four groups. The first, they don't want the tourists to harm their environment. The second, they want to the local communities to be more involved in marine tourism. The third, they think the work as a marine tour guide is still associated with the life of a small island community. And the fourth they think the work as a tour guide is more promising financially, in financial terms.

From the interview results, showed there are differences in the reasons between students in Tidung Island and the Harapan Island. In Tidung, $50 \%$ of students reasoned revenue as a tour guide more promising financially, and there are $30 \%$ of the students reasoned that local residents should have contribute more. Only $20 \%$ have a reason to prevent the tourist damaging the environment. No one thinks job as a tour guide were still associated to the life on a small island.

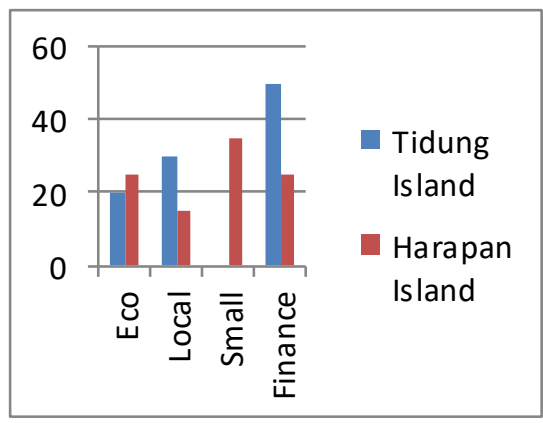

Fig. 3. The reason to become a tour guide

The students who come from Harapan Island has a different reason related to their readiness as a tour guide. The most dominant reason are the job as tour guides still associated to the life of on a small island $(35 \%)$. The students with the reasons is to prevent tourist to not damage the environment (25\%). The ones that have reason that local communities have more roles in marine tourism are $15 \%$ and the ones that think 
work as tourist guides will financially more promising as much as $25 \%$.

\section{- Readiness for Doing Conservation}

In Tidung island, some parts of the island still have true mangrove and has been there's for a long time. That it led to a very good students' knowledge about mangrove ecosystem and the needs to conserve it. Moreover, the island of Tidung Kecil is become a Marine Protected Area that belong to the Government of Jakarta. Unfortunately, not all of them have the will to do the conservation.

Meanwhile, the students at Harapan Island think mangrove conservation became one of the flagship programs of the government. So for the time being, the students considered that the mangrove have to be conserved. They considered it is reasonable to preserve mangrove. In some government programs in Harapan Island, some families were involved in the project. For example, they involved in sowing and planting mangrove seedlings

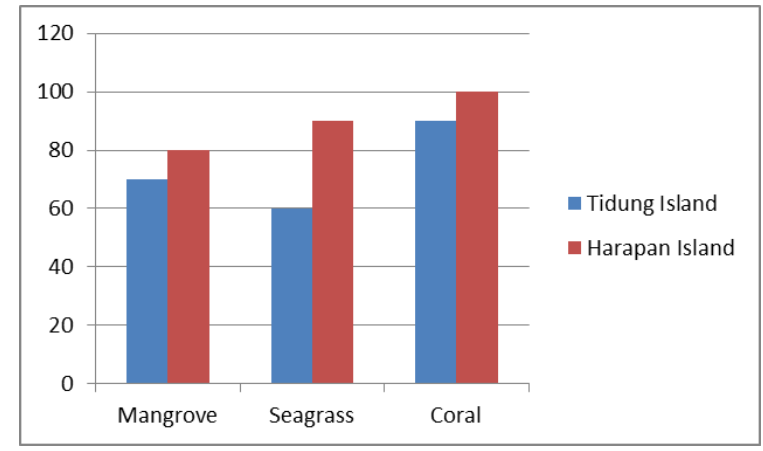

Fig.4. The percentage of students who are willing to do the conservation

They just realized that their future as the younger generation should continue maintaining the mangrove, with or without the government program. Their knowledge of mangrove is limited only to the planted mangrove species at Harapan Island. With economic reasons so the fish their father catch will constantly a lot, almost all of the participants are interested and willing to preserve mangrove.

There are in increases in opinion about the importance of seagrass for the life of fish and for disaster reduction caused by abrasion. Seagrass in Tidung Island and Harapan Island both have damaged a lot. According to the students in Tidung island, will be more difficult to recover because some damage related to the tourists. Meanwhile, in Harapan Island, the damage mostly caused by the treatment of the fisherman who are not yet realizing the importance of the seagrass. So the students still wish the conservation that supported by the fisherman, will be expand of seagrass and become more dense. So their family as fisherman would easily obtain the fish.

Coral reef conservation was agreed that it is needed by both of Tidung Island and Harapan Island students. As the location for marine tourism, the existence of healthy and beautiful coral reefs is an asset so that the tourists continued to come. The existence of the Marine Protected Areas (MPAs) must be supported by the whole society. Coral reef monitoring is required and can be conducted by young generations.

\section{Group Discussion Results}

Discussions were held to explore their wish, hope and aspirations to develop marine tourism based on environmental sustainability. Furthermore, also to xplore the reasons behind their opinions. Then they have to do a resume making. The resume will combine psychomotor abilities at sea, whether when they observe the mangrove, seagrass, or do the coral reefs monitoring. In this discussion several issues about Kepulauan Seribu used as a trigger to be discussed by the students. Such as, the TNKS, the not environmentally friendly fishing practice, and waste from the tourists.

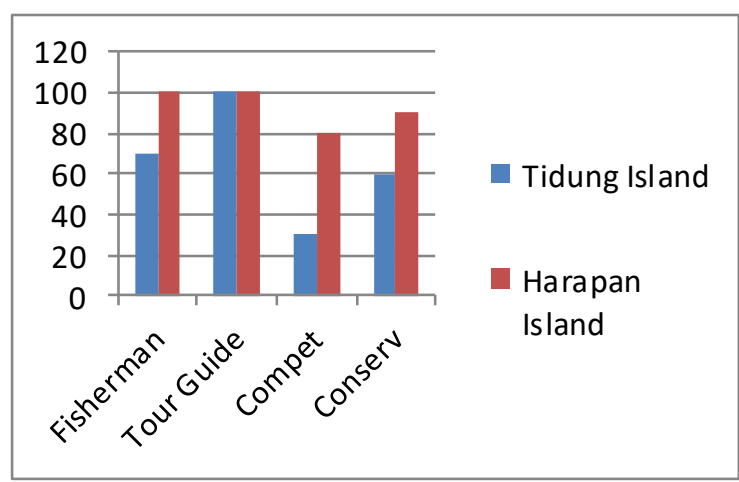

Fig.5. Parents' job background and the ability to be a potential marine tour guide and do the conservation.

The results of the discussion shows that student with daily life background give effect on their readiness to become a tour guide. Most of students' parents in Tidung island do not work as a fisherman. Most of the students' time is used for study, and beside that they use their time to help their parents in the shop and to serve the tourists, and there is only few recreation related to the ocean.

Tourism sector on Tidung island has been developing for a long time. Society has become part of the tourism. They got many variation of tourist attraction. In addition to the natural beauty view of the sea as the attraction, there is another attraction that people love the most with the water sports on the beach. It makes seagrass conservation will be constrained as long as there are attractions at the beach.

For the sustainability of marine tourism, all students were agree that is very important to monitor and maintain coral reefs to stay healthy. A lot of waste has been harming the coral reefs health. Meanwhile diving and snorkeling spots are located around the Tidung island. Although the students understand is it important, but the coral reefs monitoring training results show only $50 \%$ of students were able to do it well. 
Fisherman as the fish catcher in Tidung island spend their time to serve the needs of the tourists more than for fishing. The fishing activity that not environmentally friendly almost gone from the Tidung island now. There is only few fish around the island, that makes many fisherman need to sailed far enough to get the fish. Some of fisherman have a side job to serves in the recreational beach or delivers tourists using their boats during holidays.

Students who come from the Harapan Island mostly are children of fisherman, and most of them are from Bugis tribe. They are taught by their parents to love the sea, so they are strong and able to stay in the water for quite a long time. In addition to school time activities, they spent their free time and recreation mostly in the sea.

Harapan island is a settlements islands that provide the accommodation for snorkeling and diving for enthusiasts. Although the numbers of lodging continue to rise, actually the attractions are located outside the Harapan island. Tourist attractions like diving and snorkeling spots, located on the coral island around Harapan island. The location of coral island which is close to TNKS core area cause marine tourism activities should really be based on the preservation of ecosystems. Coral reefs damage in Harapan island partly caused by fisherman, but there is no coral destruction recently. The society supports the existence of MPAs, so are the students. They are ready to do conservation, and become a marine tour guide that care of the ecosystem sustainability.

\section{CONSCLUSIONS AND SUGGESTIONS}

The conclusion of this reseacrh is the younger generation who live on the islands farther from the city better prepared to involved in the development of marine ecotourism. Harapan Island is located farther from Jakarta to has a good quality marine ecosystems. About $80 \%$ of the younger generation have good ability in monitoring the coastal ecosystems. While younger generation in Tidung Island, which is closer to Jakarta mainland and has been developed as a tourist area for a while, are more expert in coastal tourism that tend to be recreation. Only $30 \%$ of them are ready for monitoring coastal ecosystems.

\section{ACKNOWLEDGEMENT}

To all of the Center for Marine Study Universitas Indonesia (UI) research team who had done research and training, as well as assist in the processing of data. As well Direktorat Riset Pengabdian Masyarakat Universitas Indonesia (DRPM UI) that has provide assistance for the sake of the implementation of this study.

\section{REFERENCES}

[1] Doody, J. P, "Coastal conservation and management: an ecologica perspective", Springer Science: Conservation Biology Series, New York, 2001.

[2] Estradivari, M. Syahrir, N. Susilo, S. Yusri dan S. Timotius, 2007, "Terumbu karang: laporan pengamatan jangka panjang terumbu karang Kepulauan Seribu (2004-2005)", Yayasan Terangi, Jakarta.
[3] Garoord. Brian, and Julie. Wilson, "Marine Ecotourism : Issues and Experiences", Channel View Pub: Toronto, 2005

[4] Handayani. Tuty, Riani. Widiarti, Harsono. Soepardjo, "Peningkatan Masyarakat Lokal dalam Melakukan Kegiatan Konservasi di Lingkungan Pesisir Kepulauan Seribu”, DRPM UI, 2016.

[5] Mckenzie. L. J., W. J. Lee Long, R. G. Coles, and C. A. Roder, "Seagrass-watch: community based monitoring of seagrass resources", Biol, Mari, Medit, Vol 7 (2): 393-396, 2000.

[6] Pulau Tidung Village Office, 2015, [web log post], Retrieved from www.Jakarta.tourism.go.id.

[7] Ruswadi, "Struktur Komunitas dan Kondisi Fisika Kimia Ekosistem Terumbu Karang Di Sekitar Perairan Pulau Tidung, Kepulauan Seribu", Tesis, Magister Kelautan, Universitas Indonesia, 2012.

[8] Sachoemar, S. I dan H. D. Wahjono, "Kondisi pencemaran lingkungan perairan di Teluk Jakarta", JAI Vol. 3 (1): 1-14, 2007.

[9] Suryati, "Kebiasaan makan ikan DI Pulau Tidung”, Tesis FKM UI, 2008.

[10] Widiarti, R dan M. A. Farid, "Pendidikan lingkungan laut dan pesisir untuk anak", Jurnal Mitra Bahari. Vol 2 (1): 1-5, 2007. 